\title{
EFEKTIVITAS PEMBELAJARAN MATEMATIKA MELALUI PENDEKATAN CONTEXTUAL TEACHING AND LEARNING
}

\author{
Syaiful Syamsuddin ${ }^{1 *}$ \\ Mutiara Arlisyah Putri Utami ${ }^{2}$ \\ ${ }^{1}$ Institut Bisnis dan Multimedia Asmi, Jakarta Timur, Indonesia \\ ${ }^{2}$ Universitas Islam Negeri Maulana Malik Ibrahim, Malang, Indonesia \\ syaifulsyamsuddin@ibmasmi.ac.id ${ }^{1 *}$ \\ mutiara.arlisyah@fitk.uin-malang.ac.id ${ }^{2}$
}

\begin{abstract}
Abstrak
Penelitian ini merupakan penelitian pra eksperimental dengan melibatkan satu kelas sebagai kelas eksperimen yang bertujuan untuk mengetahui keefektifan pembelajaran matematika melalui pendekatan Contextual Teaching and Learning (CTL) pada siswa sekolah menengah. Penelitian ini mengacu pada tiga kriteria yaitu pencapaian keefektifan pembelajaran pada ketuntasan pembelajaran klasikal, aktivitas siswa yang berkaitan dengan kegiatan pembelajaran, dan respon positif siswa terhadap pelaksanaan pembelajaran dengan pendekatan CTL. Desain penelitian yang digunakan adalah one-shot case study. Unit eksperimen dalam penelitian ini adalah kelas dengan jumlah siswa sebanyak 29 orang. Hasil penelitian menunjukkan bahwa pendekatan CTL pada pembelajaran matematika efektif diterapkan di Sekolah Menengah Pertama dengan rincian: (1) Rata-rata nilai (post-test) hasil belajar matematika siswa adalah 81,62 dengan standar deviasi 7,18. Hasil tersebut menunjukkan bahwa 28 siswa (96,55\%) telah mencapai ketuntasan individu atau ketuntasan klasikal telah terpenuhi; (2) Rata-rata persentase siswa yang mencapai frekuensi kegiatan efektif sebesar 76,3\%; dan (3) Respon siswa menunjukkan respon positif terhadap pendekatan CTL dengan nilai prsentase sebesar 77,87\%.
\end{abstract}

Kata Kunci: Efektivitas, Pembelajaran Matematika, Contextual Teaching and Learning.

\section{Pendahuluan}

Matematika merupakan salah satu subjek pembelajaran yang selalu dimuat dalam satuan pendidikan, baik satuan pendidikan dasar dan satuan pendidikan menengah. Prayitno \& Suarniati (2017) menyatakan bahwa mata pelajaran matematika perlu diberikan kepada semua peserta didik mulai dari sekolah dasar untuk membekali peserta didik dengan kemampuan berpikir logis, analitis, sistematis, kritis dan kreatif, serta kemampuan bekerja sama.

Hal-hal Matematika merupakan mata pelajaran yang mempunyai peran yang penting dalam aspek dan perkembangan kehidupan manusia (Curri, 2012) khususnya bagi peserta didik, karena berfungsi untuk mengembangkan kemampuan berkomunikasi dengan menggunakan simbol-simbol serta menggunakan ketajaman penalaran untuk menyelesaikan permasalahan yang terjadi dalam kehidupan sehari-hari. Baykul (2009) menyatakan bahwa matematika merupakan alat penting yang digunakan untuk memecahkan masalah baik sains maupun kehidupan sehari-hari dan membantu kita untuk berpikir kreatif dan kritis, selain itu matematika juga dapat memprakarsai gagasan untuk berfikir secara logis dan sistematis (Rattanatumma, 
2016). Namun, keluhan dalam mempelajari matematika yang banyak terdengar dalam dunia pendidikan adalah banyak siswa menengah yang mengeluh dikarenakan sering mengalami kesulitan dalam memahami soal-soal matematika. Hal ini dikarenakan matematika merupakan subjek yang hanya berurusan dengan angka dan ini mengalihkan perhatian peserta didik untuk belajar dan merupakan subjek yang membosankan (Department of Curriculum Instruction Development, 2001) dan menjadi mata pelajaran yang tidak disukai oleh anak-anak (Russefendi ,1989). Selain itu, matematika menjadi sulit karena banyak guru yang mengajarkan matematika dengan materi dan metode yang tidak menarik, dimana guru menerangkan, sementara siswa hanya mencatat (Zulkardi, 2000). Pembelajaran seperti ini didominasi oleh guru, sementara siswa cenderung pasif menerima rumus tanpa kontribusi dalam proses belajar mengajar, sehingga tidak memungkinkan bagi siswa untuk memaksimalkan dan mengkonstruksi penguasaannya terhadap pengetahuan dan keterampilan yang menjadi sasaran pembelajaran (Sumedi, 2012).

Urutan Pembelajaran yang baik adalah pembelajaran yang diberikan oleh guru didasarkan pada struktur dan aktivitas pembelajaran yang sangatlah terbimbing sehingga siswa ikut berkontribusi langsung dalam pembelajaran (Syamsuddin \& Istiyono, 2018). Saragih \& Surya (2017) menjelaskan bawha guru memiliki peran yang aktif dalam pembelajaran dan tentunya merupakan posisi yang sangat penting untuk pembelajaran yang efektif. Kompetensi yang dimiliki oleh seorang guru harus dapat diandalkan dalam proses pembelajaran, termasuk dalam menentukan model atau metode pembelajaran yang sesuai dengan materi dikarenakan keefektifan pembelajaran dapat tercapai apabila kesesuaian pembelajaran sesuai dengan materi yang diajarkan (Brew, 2011). Hal ini merupakan aspek penting dalam pembelajaran siswa karena siswa membutuhkan strategi yang relevan dalam mengatur usaha mereka (Corno \& Rohrkemper, 1985). Pemilihan model atau metode yang tepat dan strategi belajar yang digunakan oleh peserta didik akan sangat membantu dalam keberhasilan pembelajaran (Gani, 2008). Model atau metode pembelajaran yang baik untuk diimplementasikan adalah model atau metode yang dapat meningkatkan kemampuan siswa untuk melakukan aktivitas yang disertai dengan respon positif dalam pembelajaran, sehingga bisa menciptakan pembelajaran yang efektif (Anthony \& Walshaw, 2009).

Efektif dapat diartikan sebagai sesuatu yang dapat memberikan hasil. Efektivitas dapat diartikan suatu tingkat keberhasilan yang bisa dicapai dari suatu cara dengan tujuan tertentu yang ingin dicapai. Efektivitas dalam belajar adalah konsep yang lebih luas yang mencakup berbagai faktor di dalam maupun di luar diri (Saragih \& Surya, 2017). Slavin (Saragih \& Surya, 2017) menyatakan bahwa suatu pembelajaran dapat dikatakan efektif bila mencapai tujuan yang 
diinginkan, baik dari sisi tujuan belajar maupun prestasi siswa yang telah dimaksimalkan, sehingga indikator keefektifan meliputi (1) Ketuntasan hasil belajar matematika siswa, (2) aktivitas siswa dalam proses pembelajaran, dan (3) respon positif siswa terhadap kegiatan pembelajaran.

Oleh karena itu, dalam proses pembelajaran matematika diperlukan suatu pendekatan atau metode pembelajaran yang baru yang lebih memberdayakan siswa. Suatu pendekatan belajar yang tidak mengharuskan siswa menghapal fakta-fakta tetapi mendorong siswa unuk mengkonstruksikan pengetahuan di benak mereka sendiri. Salah satu pendekatan yang cocok digunakan adalah pendekatan Contextual Teaching and Learning (CTL).

Contextual Teaching and Learning (CTL) adalah salah satu pendekatan pembelajaran yang menjadikan permasalahan kehidupan sehari-hari atau masalah seputar siswa sebagai objek pembelajaran mereka (Khotimah, 2016). Pembelajaran matematika dengan pendekatan Contextual Teaching and Learning (CTL) dilaksanakan dengan menggunakan peristiwaperistiwa atau benda-benda yang berasal dari kehidupan sehari-hari siswa. Sebagaimana Nurhadi (Rusman, 2010:189) mengungkapkan bahwa pembelajaran kontekstual merupakan konsep belajar yang mampu membantu guru mengaitkan antara materi yang diajarkannya dengan situasi dunia nyata siswa dan mendorong siswa membuat hubungan antara pengetahuan yang dimilikinya dengan penerapannya dalam kehidupan mereka sebagai anggota keluarga dan masyarakat. Pembelajaran seperti ini mampu mengantarkan siswa dalam merespon setiap masalah dengan baik. Hal ini disebabkan karena dalam kehidupan sehari-hari, siswa telah mengenal masalah tersebuta.

Berns \& Erickson (2001) bahwa Contextual Teaching and Learning adalah sebuah konsep belajar mengajar membantu guru menguhubungkan isi dari materi pelajaran dengan situasi dunia nyata dan memotivasi para siswa untuk dapat mengaitkan antara pengetahuannya dengan konteks kehidupan sehari-hari. Sejalan dengan pendapat sebelumnya, Johnson (Rusman, 2010) menyampaikan jika pembelajaran kontekstual memungkinkan siswa dapat menghubungkan subjek akademik dengan kehidupan sehari-hari mereka untuk menemukan makna. Hal Ini dapat memperbesar konteks pribadi mereka lebih jauh lagi, dengan memberikan pengalaman kepada siswa yang dapat merangsang otak untuk membuat koneksi baru dan menemukan pengetahuan yang baru.

Howey R, Keneth (Rusman, 2013) mendefinisikan pembelajaran kontekstual adalah pengajaran yang memungkinkan pembelajaran di mana siswa menerapkan pemahaman dan kemampuan akademis mereka dalam berbagai konteks baik didalam maupun diluar sekolah untuk memecahkan masalah secara sendiri maupun dengan orang lain. Hasani (2016) 
mengungkapkan bahwa prinsip CTL dapat memudahkan siswa untuk memahami mata pelajaran instruksional dan mampu mengembangkan gagasan kreatif serta menjadikan siswa mampu mengaitkan antara pengetahuan yang dimiliki dan dunia nyata. Konteks dengan metode seperti ini berkaitan dengan pengalaman, kehidupan pribadi, hubungan masyarakat, dan lingkungan.

Dengan konsep tersebut, diharapkan mampu menciptakan pembelajaran matematika menjadi lebih efektif dan bermakna bagi siswa. Untuk itu, penelitian ini bertujuan untuk mengetahui keefektifan pembelajaran matematika dengan pendekatan contextual teaching and learning ditinjau dari ketuntasan hasil belajar matematika siswa, aktivitas siswa dalam proses pembelajaran, dan respon positif siswa terhadap kegiatan pembelajaran.

\section{Metode Penelitian}

Jenis penelitian ini adalah penelitian pre-experiment yang melibatkan satu kelas sebagai kelas eksperimen dengan tujuan untuk mengetahui efektivitas pembelajaran matematika melalui pendekatan Contextual Teaching And Learning (CTL) pada siswa Sekolah Menengah Pertama (SMP).

Sampel penelitian terdiri dari satu kelas dengan jumlah siswa sebanyak 29 orang dan menggunakan simple random sampling sebagai teknik pengambilan sampelnya. Kemudian, instrumen yang digunakan adalah instrumen tes, lembar observasi dan angket. Instrumen tes digunakan untuk mengukur ketuntasan hasil belajar matematika siswa, lembar observasi untuk mengetahui aktivitas siswa dalam pembelajaran dan angket untuk mengetahui tanggapan atau respon siswa.

Desain penelitian menggunakan The One Shot Case Study, sedangkan pembelajaran dalam penelitian ini mengikuti tahapan pendekatan contextual teaching and learning. Pada tahap ini, peneliti menerapkan pendekatan tersebut pada kegiatan pembelajaran sesuai dengan kegiatan pembelajaran yang telah disusun dalam Rencana Pelaksanaan Pembelajaran (RPP), observasi terhadap aktivitas siswa, membagikan angket respon siswa dan mengukur hasil belajar siswa setelah diterapkan pendekatan contextual teaching and learning.

\section{Hasil dan Pembahasan}

Ketuntasan belajar siswa diketahui setelah peneliti memberikan tes kepada siswa yang sebelumnya telah diterapkan pendekatan contextual teaching and learning. Berikut disajikan dalam tabel 1 hasil analisis belajar siswa berikut ini: 
Tabel 1. Statistika Skor Hasil Belajar Matematika Siswa

\begin{tabular}{cc}
\hline Statistika & Nilai Statistika \\
\hline Ukuran sampel & 29 \\
Nilai tertinggi & 95 \\
Nilai terendah & 65 \\
Skor ideal & 100 \\
Rentang nilai & 30 \\
Nilai rata-rata & 81,62 \\
Nilai tengah & 83 \\
Variansi & 51,60 \\
Standar deviasi & 7,18 \\
\hline
\end{tabular}

Tabel 1 menunjukkan hasil belajar matematika setelah dilakukan proses belajar mengajar dengan menggunakan pendekatan CTL bahwa nilai rata-rata sebesar 81,62. Berdasarkan skor tersebut ketika dikonversi ke dalam 5 kategori maka skor rata-rata hasil belajar matematika setelah diajar dengan menggunakan pendekatan CTL tergolong kategori tinggi. Selanjutnya, data tersebut dianalisis berdasarkan kriteria pada tabel 2 berikut:

Tabel 2. Statistika Skor Hasil Belajar Matematika Siswa

\begin{tabular}{cccc}
\hline Interval Skor & Kategori & Frekuensi & Persentase (\%) \\
\hline $0 \leq \times<70$ & Tidak Tuntas & 1 & 3,45 \\
$70 \leq \times \leq 100$ & Tuntas & 28 & 96,55 \\
\hline
\end{tabular}

Tabel 2 menggambarkan bahwa siswa yang tidak tuntas sebanyak 1 orang dengan persentase 3,45\% sedangkan siswa yang memenuhi kriteria ketuntasan individu sebanyak 28 orang dengan persentase $96,55 \%$, maka disimpulkan jika hasil belajar matematika siswa setelah diterapkan pendekatan CTL memenuhi kriteria ketuntasan klasikal yang berarti pendekatan tersebut efektif diterapkan pada pembelajaran matematika.

Selanjutnya, hasil analisis mengenai akitivitas siswa dalam pembelajaran matematika dengan pendekatan contextual teaching and learning, peneliti melakukan observasi dengan 7 komponen utama pendekatan tersebut. Berikut disajikan dalam tabel 3 hasil analisis aktivitas siswa berikut ini:

Tabel 3. Deskripsi Aktivitas Siswa dalam Pembelajaran

\begin{tabular}{lccccccc}
\hline \multirow{2}{*}{$\begin{array}{l}\text { Komponen Teramati } \\
\text { Aktivitas Positif }\end{array}$} & I & II & III & IV & V & Rata-rata & (\%) \\
\hline Kehadiran & 26 & 29 & 27 & 25 & P & 26,75 & 92,24
\end{tabular}




\begin{tabular}{lccccccc}
\hline Komponen Teramati & \multicolumn{9}{c}{ Pertemuan ke- } & & Rata-rata & (\%) \\
Bertanya dan & I & II & III & IV & V & & \\
Konstruktivisme & 23 & 27 & 24 & 23 & O & 24,25 & 83,62 \\
Pemodelan & 23 & 26 & 25 & 20 & T & 23,50 & 81,03 \\
Inquiry & 23 & 26 & 23 & 21 & & 23,25 & 80,17 \\
Masyarakat belajar & 25 & 28 & 26 & 22 & T & 25,25 & 87,06 \\
Presentasi & 23 & 26 & 24 & 23 & S & 24,00 & 82,76 \\
& & & & & T & & 27,58 \\
Refleksi & 9 & 7 & 8 & 8 & & 8,00 & \\
Jumlah & 152 & 169 & 157 & 142 & & 155 & \\
Rata-rata & 21,71 & 24,14 & 22,43 & 20,29 & & 22,14 & 76,35 \\
Presentase rata-rata (\%) & 74,86 & 83,24 & 77,34 & 69,99 & & 76,35 & \\
Aktivitas Negatif & & & & & & & \\
Aktivitas lain & 4 & 5 & 6 & 4 & & 4,75 & \\
Jumlah & 4 & 5 & 6 & 4 & & 4,75 & 16,38 \\
Rata-rata & 4 & 5 & 6 & 4 & & 4,75 & \\
Presentase Rata-rata (\%) & 13,79 & 17,24 & 20,68 & 13,79 & & 16,38 & \\
\hline
\end{tabular}

Tabel 3 menunjukkan bahwa rata-rata persentase aktivitas aktif siswa terhadap pembelajaran matematika, mulai dari rata-rata persentase komponen ke-1 sampai komponen ke-7 yaitu 76,35\%. Hal ini berarti bahwa siswa terlibat aktif dalam pembelajaran matematika yang berarti CTL efektif diterapkan pada pembelajaran matematika ditinjau dari segi aktivitas siswa dalam pembelajaran.

Tabel 4. Deskripsi Respon Siswa

\begin{tabular}{lcc}
\hline \multicolumn{1}{c}{ Uraian Pertanyaan } & Ya & (\%) \\
\hline $\begin{array}{l}\text { Apakah menurut Anda pelajaran matematika adalah pelajaran yang } \\
\text { menyenangkan? }\end{array}$ & 26 & 89,66 \\
$\begin{array}{l}\text { Apakah pembelajaran yang diterapkan oleh guru membuat Anda tertarik } \\
\text { dengan pelajaran matematika? }\end{array}$ & 26 & 89,66 \\
$\begin{array}{l}\text { Apakah pembelajaran yang diterapkan oleh guru memudahkan Anda } \\
\text { untuk memahami materi pelajaran matematika? }\end{array}$ & 20 & 68,97 \\
$\begin{array}{l}\text { Apakah pembelajaran yang diterapkan oleh guru membuat Anda berani } \\
\text { mengungkapkan pendapat? }\end{array}$ & 24 & 82,75 \\
$\begin{array}{l}\text { Apakah Anda lebih senang pembelajaran matematika yang diterapkan } \\
\text { oleh guru dibandingkan dengan guru lain? }\end{array}$ & 16 & 55,17 \\
$\begin{array}{l}\text { Apakah Anda senang bekerja sama dalam mengerjakan soal matematika? } \\
\begin{array}{l}\text { Apakah Anda lebih termotivasi belajar matematika setelah mendapat } \\
\text { pembelajaran dari guru? }\end{array}\end{array}$ & 27 & 93,10 \\
$\begin{array}{l}\text { Apakah Anda lebih cepat memahami pelajaran matematika dengan cara } \\
\text { guru memberikan pelajaran? }\end{array}$ & 24 & 75,86 \\
\hline
\end{tabular}


Apakah Anda senang melakukan tanya jawab dalam belajar matematika? $\quad 27 \quad 93,10$

Apakah Anda senang belajar matematika dengan cara menemukan sendiri?

Apakah Anda senang diberikan penilaian setiap akhir pertemuan?

$23 \quad 79,31$

Apakah Anda senang diberikan tugas pekerjaan rumah (PR) setiap akhir pembelajaran matematika?

16

Jumlah

Berdasarkan penjabaran dari respon siswa tersebut diperoleh kesimpulan bahwa ratarata persentase respon siswa yang diajar melalui pendekatan CTL adalah 77,87\%. Hal ini mengindikasikan bahwa pendekatan CTL efektif diterapkan pada pembelajaran matematika ditinjau dari respon siswa.

Hasil analisis pada yang ditunjukkan dari tabel 2,3 dan 4 bahwa pendekatan CTL efektif diterapkan pada pembelajaran matematika. Hal ini menjadikan siswa telah terlibat secara aktif dan dominasi guru dalam pembelajaran dapat berkurang. Lebih dari itu, hubungan antara guru dan siswa dapat dikatakan sebagai interaksi sosial. Sebagaimana Utami \& Syamsuddin (2020) menyatakan bahwa interaksi sosial merupakan suatu hubungan sosial yang melibatkan antar personal atau antar kelompok dengan lainnya, maupun antara personal dengan kelompok.

Selvianiresa \& Prabwanto (2017) mengatakan bahwa pendekatan Contextual Teaching and Learning (CTL) adalah pendekatan yang melibatkan siswa aktif dalam proses belajar untuk menemukan konsep yang dipelajari dari pengetahuan dan pengalaman para siswa. Hasil ini sesuai dengan pernyataan Nuryadi (2015) dan Saragih \& Surya (2017) bahwa pendekatan Contextual Teaching and Learning efektif diterapkan pada pembelajaran matematika.

Piaget (Maulana, 2011) menyatakan bahwa dengan belajar mampu memberikan siswa sebuah karya dalam menciptakan hal baru dengan menghubungkan pengalaman dan membangun pikiran mereka sendiri. Saat siswa menghubungkan matematika dengan kehidupan nyata, maka siswa dapat melihat antara konsep yang bisa dipelajari dengan konsep yang telah dipelajari. Serupa dengan pendapat Berns \& Erickson (2001) bahwa CTL mampu memotivasi para siswa untuk memperolah hasil yang maksimal karena siswa mampu mengaitkan antara pengetahuannya dengan konteks kehidupan sehari-hari. Lebih lanjut khaefiatunnisa (2015) mengungkapkan bahwa pendekatan CTL dapat memberikan tanggapan positif saat diterapkan pada pembelajaran. Respon positif yang terjadi tidak terlepas dari pembelajaran matematika dengan pendekatan CTL yang mendukung pembelajaran efektif yang berasal dari interaksi positif pada proses pembelajaran dan mampu meningkatkan daya ingat siswa (Evans, 2010). 


\section{Kesimpulan dan Saran}

Berdasarkan rincian hasil dari pemaparan diatas terlihat bahwa ketuntasan belajar siswa terpenuhi dengan presantese $96,55 \%$ dan masuk dalam kategori efektif. Pada analisis aktivitas siswa dan respon siswa pada pembelajaran matematka juga tergolong dalam katgeori efektif, masing-masing dengan presentase $76,35 \%$ untuk aktivitas suswa dan $77,87 \%$ untuk respon siswa. Jadi, secara keseluruhan dapat disimpulkan bahwa pembelajaran matematika dengan pendekatan Contextual Teaching and Learning (CTL) efektif diterapkan pada siswa SMP ditinjau dari ketuntasan belajar siswa, aktivitas siswa dalam proses pembelajaran, dan respon positif siswa terhadap kegiatan pembelajaran.

Pembelajaran matematika dengan pendekatan CTL dapat diterapkan disekolah untuk dijadikan sebagai metode pembelajaran yang efektif. Dengan keterbatasan yang dimiliki oleh peneliti, antara lain waktu, sarana dan prasarana, dll, sehingga peneliti tidak dapat melihat lebih jauh mengenai pendekatan CTL. Untuk itu, diharapkan pada peneliti selanjutnya dapat meneliti lebih mendalam mengenai pendekatan CTL ditinjau dari aspek atau perspektif yang berbeda.

\section{DAFTAR PUSTAKA}

Anthony, G., \& Walshaw, M. (2009). Characteristics of effective teaching of mathematics: A view from the West. Journal of Mathematics Education, 2(2), 147-164.

Brew, L. (2011). Mathematical Activities and Classroom Based Factors That Support Senior High School Studentse Mathematical Performance. British Journal of Arts and Social Sciences, 2(1), 11-20.

Baykul, Y. (2000). Illköğretimde matematik ögrretimi: 1-5. sınıflar için. Pegem A. Yayıncılık.

Berns, R. G., \& Erickson, P. M. (2001). Contextual teaching and learning: Preparing students for the new economy (Vol. 5). Columbus, $\mathrm{OH}$ : National Dissemination Center for Career and Technical Education.

Curri, E. (2012). Using computer technology in teaching and learning mathematics in an Albanian upper secondary school: the implementation of simReal in trigonometry lessons (Master's thesis, Universitetet i Agder; University of Agder).

Corno, L., \& Rohrkemper, M. (1985). The intrinsic motivation to learn in classrooms. Research on motivation in education, 2, 53-90.

Depertment of Curriculum Instruction Development. (2001). Mathematics by STAD Manual. Kurusapa Printing Ladphroa; Bangkok.

Evans, S. (2010). The role of multicultural literature interactive read-alouds on student perspectives toward diversity. Journal of Research in Innovative Teaching, 3(1). 
Hasani, A. (2016). Enhancing Argumentative Writing Skill through Contextual Teaching and Learning. Educational Research and Reviews, 11(16), 1573-1578.

Khaefiatunnisa, K. The Effectiveness of Contextual Teaching And Learning In Improving Students'reading Skill In Procedural Text (A Quasi-Experimental Study of the Second Grade Students at One Vocational School in Bandung). Journal of English and Education, 3(1), 80-95.

Khotimah, R. P., \& Masduki, M. (2016). Improving teaching quality and problem solving ability through contextual teaching and learning in differential equations: A lesson study approach. JRAMathEdu (Journal of Research and Advances in Mathematics Education), 1(1), 1-13.

Rattanatumma, T., \& Puncreobutr, V. (2016). Assessing the Effectiveness of STAD Model and Problem Based Learning in Mathematics Learning Achievement and Problem Solving Ability. Journal of Education and Practice, 7(12), 194-199.

Ruseffendi, E. T. (1980). Pengajaran matematika modern: untuk orang tua murid guru dan SPG/oleh ET Ruseffendi.

Rusman. (2011). Model-model pembelajaran: Mengembangkan profesionalisme guru. Rajawali Pers/PT Raja Grafindo Persada.

Saragih, D. I., \& Surya, E. (2017). Analysis the Effectiveness of Mathematics Learning Using Contextual Learning Model. International Journal of Sciences: Basic and Applied Research (IJSBAR), 34(1), 135-143.

Selvianiresa, D., \& Prabawanto, S. (2017, September). Contextual teaching and learning approach of mathematics in primary schools. In Journal of Physics: Conference Series (Vol. 895, No. 1, p. 012171). IOP Publishing.

Syamsuddin, S., \& Istiyono, E. (2018, September). The effectiveness of mathematics learning through contextual teaching and learning approach in Junior High School. In AIP Conference Proceedings (Vol. 2014, No. 1, p. 020085). AIP Publishing LLC.

Utami, M. A. P., \& Syamsuddin, S. (2020). PERUBAHAN PERILAKU NOMOPHOBIA MELALUI PENDEKATAN INTERAKSI SOSIAL: SINGLE CASE RESEARCH (SCR). Preschool: Jurnal Perkembangan dan Pendidikan Anak Usia Dini, 2(1), 133-140.

Zulkardi, Z. (2000). Realistic Mathematics Education Theory Meets Web Technology. 